\section{DCPTA Ineffective as a Production Aid on Field-grown Tomato and Pepper}

\author{
T.K. Hartz and L.J. Kies \\ Department of Vegetable Crops, University of California, Davis, CA 95616
}

A. Baameur

University of California Cooperative Extension, Riverside County, Moreno Valley, CA 92557

D.M. May

University of California Cooperative Extension, Fresno County, Fresno, CA 93702

Additional index words. Lycopersicon esculentum, Capsicum annuum, bioregulator, fruit quality

Abstract. Application of DCPTA, as a seed treatment and a foliar spray, was evaluated for effects on productivity and fruit quality of processing tomato (Lycopersicon esculentum Mill.) and fresh-market pepper (Capsicum annuum $\mathrm{L}$.). Two field trials for each crop were conducted in California during 1992. No DCPTA treatment was effective in increasing vegetative growth or fresh fruit yield of either crop at any site. Total soluble solids concentration and color of tomato fruits were unaffected by DCPTA, regardless of application method. We conclude that DCPTA is not a useful production aid for fieldgrown tomato or pepper. Chemical name used: 2-(3,4-dichlorophenoxy) triethylamine (DCPTA).

DCPTA is a tertiary amine bioregulator reported to improve growth, yield, and fruit quality of a variety of crops, including pepper and tomato (Keithly et al., 1991a). This compound has been reported to increase root development and leaf area of radish (Raphanus sativus L.; Keithly et al., 1992) and beet (Beta vulgaris L.; Keithly et al., 1992), increase chloroplast volume per cell in spinach (Spinacia oleracea L.; Keithly et al., 1991a), and increase $\mathrm{CO}_{2}$ fixation in cotton (Gossypium hirsutum L.; Gausman et al., 1985). These studies were all conducted under greenhouse conditions.

The effects of DCPTA on tomato has been studied extensively, again mostly under greenhouse conditions. Reported effects included enhanced seedling vigor and vegetative growth, increased fruit yield, higher fruit soluble solids concentration (SSC), and increased concentration of lycopene and beta carotene in fruit (Hsu and Yokoyama, 1991; Keithly et al., 1990b, 1991b). In the only published study involving field-grown tomato, Keithly et al. (1991b) reported significant increases in fruit SSC and lycopene and beta carotene content. Optimal concentration to elicit positive effects on tomato was $30 \mu \mathrm{M}$, whether as a pregermination seed treatment or a foliar application. The objective of our studies was to evaluate the effects of DCPTA on field-grown tomato and pepper.

Received for publication 4 Feb. 1994. Accepted for publication 20 Aug. 1994. The cost of publishing this paper was defrayed in part by the payment of page charges. Under postal regulations, this paper therefore must be hereby marked advertisement solely to indicate this fact.

Purified DCPTA was obtained from Henry Yokoyama (U.S. Dept. of Agriculture-Agricultural Research Service, Fruit and Vegetable Chemistry Laboratory, Pasadena, Calif.). Trials with pepper were conducted in a commercial field near Coachella, Calif., and at the Univ. of California at Davis (UCD). 'Jupiter' pepper seed was soaked for $6 \mathrm{~h}$ in a solution of DCPTA $(3,30$, or $300 \mu \mathrm{M})$ plus surfactant $(0.1 \%$ Tween 80$)$ at $22 \mathrm{C}$; the solutions were aerated hourly by vigorous shaking. Seed were then air-dried at $22 \mathrm{C}$ before being planted in a peat-vermiculite medium in transplant trays (15- $\mathrm{cm}^{3}$ cell volume). Foliar treatment $(6,30$, and $150 \mu \mathrm{m}$ DCPTA plus $0.1 \%$ Tween 80 ) was applied in the greenhouse when plants were at the four true-leaf stage. Plants were sprayed to runoff with a misting sprayer. Seedlings were transplanted 7 Feb. (Coachella) and 20 May 1992 (UCD) in a two-row configuration per 1.5 -m-wide raised bed at a population of 43,000 plants/ha. The design was a randomized complete block with four 6-m-long, single-bed replications. Both sites were drip-irrigated; black polyethylene bed mulch was used at the Coachella site only. Standard commercial fertility and pest management practices were followed. On 28 July, four whole plants per plot were harvested from the UCD trial, separated into fruit and vegetative tissue, and ovendried at $60 \mathrm{C}$ for total dry-matter determination. Fruit harvest dates were 15 May and 5 June (Coachella) and 19 Aug. and 4 Sept. (UCD).

Processing tomato trials were conducted at the Univ. of California West Side Field Station (WSFS) and at UCD. At WSFS, 'Brigade' and VF 6203 seed was treated as described above for pepper and planted into the field on $1 \mathrm{Apr}$. Field configuration was a single-plant row on $1.65-\mathrm{m}$-wide raised beds at a population of 22,000 plants/ha. The design was a randomized complete block with six 5-m-long, singlebed replications. A foliar DCPTA application was also evaluated; $30 \mu \mathrm{M}$ DCPTA plus $0.1 \%$ Tween 80 was sprayed to runoff with a misting sprayer on 6 May, just before first bloom.

At UCD, two types of DCPTA seed treatments were evaluated: tomato seed treated as described and dried before planting, and seed planted directly after treatment, without drying. Seed were planted in a peat-vermiculite medium in transplant trays on 18 Apr. and greenhouse-grown until transplanted into the field on 25 May. Additionally, a foliar application of $30 \mu \mathrm{M}$ DCPTA plus $0.1 \%$ Tween 80 was evaluated; the material was sprayed to runoff on 7 June, 13 days after transplanting.

Tomato plots were either drip- (UCD) or furrow-irrigated (WSFS). Standard commercial fertility and pest management practices were followed. Plots were harvested on 29 July (WSFS) or 5-6 Sept. (UCD) when $\approx 90 \%$ of fruit were red. At UCD, a commutated sample of $5 \mathrm{~kg}$ of ripe fruit per plot was evaluated for color with an Agtron E-5M reflectance colorimeter (Agtron, Sparks, Nev.) and for SSC by refractometry.

\section{Results and Discussion}

DCPTA, whether applied as a seed treatment or foliar spray, had no effect on vegetative development of greenhouse transplants of either pepper or tomato; similarly, DCPTA had no significant effect on dry weight of field-grown plants or assimilate partitioning between fruit and vegetative tissue (data not shown). No positive effects of DCPTA treatment were observed in pepper fruit yield at either site (Table 1). Yields ranged from 39.5 to 48.3 and 49.2 to $50.6 \mathrm{~kg} / \mathrm{plot}$ at Coachella and UCD, respectively.

Tomato was equally unresponsive. At WSFS, DCPTA treatment did not affect fruit

Table 1. Effect of DCPTA on fruit yield of fieldgrown pepper.

\begin{tabular}{|c|c|c|}
\hline Source & $\mathrm{df}$ & MS \\
\hline \multicolumn{3}{|l|}{ Coachella } \\
\hline Block & 3 & $56.0^{\mathrm{ss}}$ \\
\hline Treatment & 6 & $55.8^{\mathrm{Ns}}$ \\
\hline Error & 18 & $79.6^{\mathrm{Ns}}$ \\
\hline \multicolumn{3}{|c|}{ Contrasts } \\
\hline \multicolumn{3}{|c|}{ Foliar treatment } \\
\hline Linear & 1 & $80.8^{\mathrm{ss}}$ \\
\hline Quadratic & 1 & $53.4^{\mathrm{Ns}}$ \\
\hline \multicolumn{3}{|c|}{ Seed treatment } \\
\hline Linear & 1 & $2.8^{\mathrm{Ns}}$ \\
\hline Quadratic & 1 & $111.9^{\mathrm{Ns}}$ \\
\hline \multicolumn{3}{|l|}{$\mathrm{UCD}^{\mathrm{z}}$} \\
\hline Block & 3 & $7.4^{\mathrm{Ns}}$ \\
\hline Treatment & 3 & $1.2^{\mathrm{Ns}}$ \\
\hline Error & 9 & $9.2^{\mathrm{Ns}}$ \\
\hline \multicolumn{3}{|l|}{ Contrasts } \\
\hline \multicolumn{3}{|c|}{ Foliar treatment } \\
\hline Linear & 1 & $0.4^{\mathrm{Ns}}$ \\
\hline Quadratic & 1 & $1.6^{\mathrm{Ns}}$ \\
\hline
\end{tabular}


Table 2. Effect of DCPTA on fruit yield of fieldgrown tomato, WSFS. ${ }^{2}$

\begin{tabular}{lrr}
\hline Source & df & \multicolumn{1}{c}{ MS } \\
\hline Block & 5 & $1387.7^{*}$ \\
Treatment (T) & 4 & $52.6^{\mathrm{vs}}$ \\
Cultivar (C) & 1 & $83.8^{\mathrm{Ns}}$ \\
T $\times$ C & 4 & $581.9^{\mathrm{Ns}}$ \\
Error & 45 & 456.3 \\
Contrasts & & \\
$\quad$ Seed treatment & & \\
$\quad$ Linear & 1 & $21.9^{\mathrm{vs}}$ \\
$\quad$ Quadratic & 1 & $5.9^{\mathrm{Ns}}$ \\
$\quad$ Foliar treatment & 1 & $7.3^{\mathrm{Ns}}$
\end{tabular}

${ }^{2}$ WSFS $=$ Univ. of California West Side Field Station.

ws, "Nonsignificant or significant at $P \leq 0.05$, respectively.

yield (Table 2); yields ranged from 102 to 120 $\mathrm{kg} / \mathrm{plot}$, with $<6 \%$ green fruit at harvest in any treatment. DCPTA did not improve fruit yield, maturity at harvest, fruit color, or SSC at UCD (Table 3). Plants grown from DCPTA-treated seed that was not dried before sowing were less productive than those grown from seed that was dried following treatment $(45.5 \mathrm{~kg} /$ plot vs. $53.8 \mathrm{~kg} / \mathrm{plot}$, respectively). It was unclear whether this difference was related to the action of DCPTA or to the difference in state of hydration at sowing. Loss of original field data subsequent to initial review of this manuscript prevented presentation of the analysis of variance table for the UCD trial; for more detailed analysis, see Kies (1993).

These negative results do not support previous reports of strongly positive effects on these crops (Hsu and Yokoyama, 1991; Keithly et al., 1990b, 1991a, 1991b). The range of DCPTA concentrations we tested (3 to 300 $\mu \mathrm{M})$ was chosen to encompass the $30-\mu \mathrm{M}$ concentration consistently shown to elicit positive crop response (Keithly et al., 1991a). Seed treatment and foliar application of DCPTA have been effective, but neither approach showed positive response in the current study. Keithly et al. (1991b) reported that some tomato cultivars responded more favorably to DCPTA treatment than others, but positive effects were observed on all cultivars tested, including VF 6203.

Nearly all published reports examined the effects of DCPTA under laboratory or greenhouse conditions. Keithly et al. (1991b) reported that DCPTA applied as a seed treatment increased lycopene and SSC of fieldgrown fruit; DCPTA effects on yield were not reported. Despite positive effects in greenhouse tests (Gausman et al., 1985), Millhollon et al. (1987) found foliar DCPTA application

Table 3. Effect of DCPTA on fruit yield, earliness, and quality of field-grown tomato (UCD test).

\begin{tabular}{|c|c|c|c|c|c|c|}
\hline Cultivar & $\begin{array}{c}\text { Treatment } \\
\text { method }\end{array}$ & $\begin{array}{c}\text { DCPTA } \\
\text { concn } \\
(\mu \mathrm{M})\end{array}$ & $\begin{array}{c}\text { Total fruit } \\
\text { yield } \\
\text { (kg/plot) }\end{array}$ & $\begin{array}{l}\text { Red fruit } \\
\text { (\% of total) }\end{array}$ & $\begin{array}{l}\mathrm{SSC}^{y} \\
(\%)\end{array}$ & $\begin{array}{l}\text { Fruit } \\
\text { color }\end{array}$ \\
\hline \multirow[t]{5}{*}{ Brigade } & Nontreated & & 63.8 & 86 & 4.4 & 21 \\
\hline & Seed/dry & & & & & \\
\hline & sowing & 3 & 67.7 & 86 & 4.4 & 21 \\
\hline & & 30 & 57.1 & 86 & 4.3 & 21 \\
\hline & & 300 & 56.1 & 88 & 4.7 & 21 \\
\hline \multirow[t]{5}{*}{ Significance } & & & $\mathrm{L}^{\mathrm{Ns}}, \mathrm{Q}^{\mathrm{Ns}}$ & $\mathrm{L}^{\mathrm{Ns}}, \mathrm{Q}^{\mathrm{Ns}}$ & $\mathrm{L}^{\mathrm{Ns}}, \mathrm{Q}^{\mathrm{ss}}$ & $\mathrm{L}^{\mathrm{Ns}}, \mathrm{Q}^{\mathrm{Ns}}$ \\
\hline & Seed/wet & & & & & \\
\hline & sowing & 3 & 50.2 & 89 & 4.3 & 20 \\
\hline & & 30 & 47.2 & 88 & 4.4 & 21 \\
\hline & & 300 & 53.0 & 87 & 4.4 & 21 \\
\hline \multirow[t]{2}{*}{ Significance } & & & $\mathrm{L}^{\mathrm{Ns}}, \mathrm{Q}^{\mathrm{Ns}}$ & $\mathrm{L}^{\mathrm{Ns}}, \mathrm{Q}^{\mathrm{Ns}}$ & $\mathrm{L}^{\mathrm{Ns}}, \mathrm{Q}^{\mathrm{vs}}$ & $\mathrm{L}^{\mathrm{Ns}}, \mathrm{Q}^{\mathrm{Ns}}$ \\
\hline & Foliar & & 64.1 & 86 & 4.5 & 21 \\
\hline \multirow[t]{2}{*}{ Contrast } & Nontreated & & & & & \\
\hline & vs. foliar & & NS & NS & NS & NS \\
\hline \multirow[t]{5}{*}{ VF 6203} & Nontreated & & 46.4 & 80 & 4.6 & 21 \\
\hline & Seed/dry & & & & & \\
\hline & sowing & 3 & 48.0 & 83 & 4.4 & 20 \\
\hline & & 30 & 47.8 & 81 & 4.4 & 20 \\
\hline & & 300 & 46.2 & 84 & 4.5 & 22 \\
\hline \multirow[t]{5}{*}{ Significance } & & & $\mathrm{L}^{\mathrm{Ns}}, \mathrm{Q}^{\mathrm{Ns}}$ & $\mathrm{L}^{\mathrm{Ns}}, \mathrm{Q}^{\mathrm{Ns}}$ & $\mathrm{L}^{\mathrm{Ns}}, \mathrm{Q}^{\mathrm{vs}}$ & $\mathrm{L}^{\mathrm{Ns}}, \mathrm{Q}^{\mathrm{Ns}}$ \\
\hline & Seed/wet & & & & & \\
\hline & sowing & 3 & 43.3 & 82 & 4.4 & 22 \\
\hline & & 30 & 34.1 & 82 & 4.4 & 22 \\
\hline & & 300 & 45.4 & 82 & 4.3 & 22 \\
\hline \multirow[t]{2}{*}{ Significance } & & & $\mathrm{L}^{\mathrm{Ns}}, \mathrm{Q}^{\mathrm{Ns}}$ & $\mathrm{L}^{\mathrm{Ns}}, \mathrm{Q}^{\mathrm{Ns}}$ & $\mathrm{L}^{\mathrm{Ns}}, \mathrm{Q}^{\mathrm{vs}}$ & $\mathrm{L}^{\mathrm{Ns}}, \mathrm{Q}^{\mathrm{Ns}}$ \\
\hline & Foliar & & 39.4 & 80 & 4.6 & 20 \\
\hline \multirow[t]{2}{*}{ Contrast } & Nontreated & & & & & \\
\hline & vs. foliar & & NS & NS & NS & NS \\
\hline
\end{tabular}

${ }^{2} \mathrm{UCD}=$ Univ. of California at Davis

${ }^{\text {y }} \mathrm{SSC}=$ soluble solids concentration.

Ns Nonsignificant at $P \leq 0.05 ; \mathrm{L}=$ linear, $\mathrm{Q}=$ quadratic.

to be ineffective in increasing boll yield of field-grown cotton.

In summary, DCPTA did not significantly affect tomato or pepper growth or productivity in four field trials. We conclude that DCPTA, whether applied as a seed treatment or a foliar spray, is not a useful production aid for these crops under field conditions we encountered.

\section{Literature Cited}

Gausman, H.W., J.D. Burd, J. Quisenberry, H. Yokoyama, P. Dilbeck, and C.R. Benedict. 1985. Effects of dimethyleaminoethyl-3,4dichlorophenylether (DCPTA) on cotton (Gossypium hirsutum L.) growth and phenology. Bio/Technology 3:255-257.

Hsu, W.J. and H. Yokoyama. 1991. Effect of 2-(3,4dichlorophenoxy)triethylamine on tomato Lycopersicon esculentum cv. UCD-82. J. Agr. Food Chem. 39:96-98.

Keithly, J.H., H. Kobayashi, H. Yokoyama, and H.W. Gausman. 1991b. Enhanced vegetative growth and development of processing tomato by DCPTA treatment of seed. J. Amer. Soc. Hort. Sci. 116:693-696.

Keithly, J.H., H. Yokoyama, and H.W. Gausman. 1990a. Effect of dimethyleaminoethyl-3,4dichlorophenylether (DCPTA) on the growth and development of sugarbeet. Plant Sci. 68:5764.

Keithly, J.H., H. Yokoyama, and H.W. Gausman. $1990 \mathrm{~b}$. Enhanced yield of tomato in response to 2-(3,4-dichlorophenoxy) triethylamine (DCPTA). Plant Growth Regulat. 9:127-136.

Keithly, J.H., H. Yokoyama, and H.W. Gausman. 1991a. Regulation of crop growth and yield by tertiary amine bioregulators, p. 222-245. In: H.W. Gausman (ed.). Plant biochemical regulators. Marcel Dekker, New York.

Keithly, J.H., H. Yokoyama, and H.W. Gausman. 1992. Promotive effects of DCPTA on seedling development and growth of radish. J. Amer. Soc. Hort. Sci. 117:294-297.

Kies, L.J. 1993. The effects of DCPTA and related compounds on the germination, growth and yield of processing tomatoes. MS Thesis, Univ. of California, Davis.

Millhollon, E.P., C.W. Kennedy, W.C. Smith, and A.W. Beck. 1987. Effect of dimethyleaminoethyl3,4-dichlorophenylether (DCPTA) on the fruiting characteristics and yield of cotton. Proc. Beltwide Cotton Production Res. Conf. 1987. p. 74-76. 